\title{
Impaired Training-Induced Adaptation of Blood Pressure in COPD Patients: Implication of the Muscle Capillary Bed [Corrigendum]
}

\author{
Gouzi F, Maury J, Bughin F, et al. Int J Chron Obstruct \\ Pulmon Dis. 2016;11:2349-2357.
}

Page 2351, Results, Characteristics of the study subjects, right column, second paragraph, the text "Baseline muscle capillarization was assessed in a subgroup of 19 COPD patients and 17 CSs who were representative of the whole population (Table 2) and confirmed the muscle capillary rarefaction in COPD patients vs $\mathrm{CSs}(\mathrm{C} / \mathrm{F}$ ratio: $1.90 \pm 0.42$ vs $1.57 \pm 0.26 ; P<0.01)$ " should read "Baseline muscle capillarization was assessed in a subgroup of 19 COPD patients and $17 \mathrm{CSs}$ who were representative of the whole population (Table 2) and confirmed the muscle capillary rarefaction in COPD patients vs CSs (C/F ratio: $1.29 \pm 0.27$ vs $1.57 \pm 0.26 ; P<0.01)$ ".

The authors apologize for this error.

\section{Publish your work in this journal}

The International Journal of COPD is an international, peer-reviewed journal of therapeutics and pharmacology focusing on concise rapid reporting of clinical studies and reviews in COPD. Special focus is given to the pathophysiological processes underlying the disease, intervention programs, patient focused education, and self management protocols. This journal is indexed on PubMed Central, MedLine and CAS. The manuscript management system is completely online and includes a very quick and fair peer-review system, which is all easy to use. Visit http://www.dovepress.com/testimonials.php to read real quotes from published authors. 